\title{
Preface
}

Demystifying Global Macroeconomics (DGM) bridges the gap between the theoretical and practical use and understanding of international macroeconomics. For serious business and political leaders, understanding the global interconnections in economic and financial markets is crucial for making informed and well-timed decisions. DGM takes the mystery out of seemingly complex economic interactions by providing a logical framework within which to analyze the effects of economic, social, and political shocks to a nation's economy.

The contents of this book are sophisticated but not "rocket science." If I wrote it correctly, each section should follow in a logical order to build an understanding of how the global economy works. My approach is to rely on common sense, with the belief that only if a concept appeals to your sensibilities and intuition will it be remembered and used as a valuable decision-making tool. With the help of supply and demand analysis, this book explains how prices, rates, and quantities per period are determined in the real credit markets, real goods and services markets, and foreign exchange markets. It then goes on to show how these three major macroeconomic markets are interconnected.

The principles in this book have a rich history, which has evolved over time. While there is still controversy in economic circles, it is fair to say that there is much more agreement than discord. Understanding global macroeconomics brings structure and organization to commercial, financial, political, and social decisions. Its logic and circuitry are useful for analyzing current, past, and possible future economic events, and this usefulness is not tied to any geographic location.

A common denominator among all the important macroeconomic variables is that they are determined by market forces and not by managers. Nevertheless, good business managers understand how to anticipate, react to, and cope with the shifting tides of economic fortune and misfortune, just as good sailors try to anticipate, react to, and cope with changing weather conditions over which they have no control.

Possessing a solid macroeconomic framework empowers managers with the ability to:

- Create, critically evaluate, and effectively use country analyses to improve financial statement projections (e.g., income statements, balance sheets, and cash flow statements)

- Integrate anticipated economic changes and government policies into business strategies that increase competitiveness and performance

- Formulate reasoned opinions about the causes of and cures for chronic economic illnesses in countries 
- Understand the economic impact and sustainability of proposed political legislation

Economic causes and effects have short-term and long-term implications. This book views the short-term as a period from one-to-five years, which is consistent with companies' budget and business plan time horizons. It is also generally consistent with the terms of office for many countries' presidents and prime ministers. The long-term is for 10-to-20-year scenario-planning analyses. The luxury of time offers greater degrees of business flexibility and maneuverability than the short term.

By tying together relevant economic principles, this book explains how to answer questions, such as:

- What effects should U.S. tariffs on Chinese imports have on economic conditions (e.g., gross domestic product, unemployment rate, inflation rate, interest rates, and exchange rates) in the United States and China?

- Presidential candidates often promise to pass large infrastructure spending bills to repair and modernize aging roads, bridges, and airports. How should infrastructure spending, and the financing needed to support it, affect a nation's economic conditions?

- Suppose investment risks in Argentina, for instance, increase relative to the United States, causing massive sales of Argentine pesos for U.S. dollars. What effect should capital flight have on Argentina's economic conditions?

- In November 2016, India launched an ambitious demonetization program with a number of goals in mind. One of them was to have India's residents embrace cashless exchange in much greater numbers. What effect should an increase in electronic payments have on India's economy?

- Suppose the U.S. government finds a way to substantially reduce the drug abuse problem, in general, and the drug overdose problem, in particular, causing an increase in the nation's employment-to-population ratio. What effect should this successful effort have on U.S. economic conditions?

- Carbon tax proponents claim that this levy would be more effective at curbing pollution and fighting climate-change than government regulations. What effect should a carbon tax have on the adopting nation's economic conditions, government budget, and money supply?

- A border-adjustment tax would prohibit companies from deducting the costs of imported inputs from gross revenues, when they report their taxable earnings. At the same time, it would remove corporate taxes on export revenues. This combination is equivalent to a tax on imports and a subsidy for exports. What effects should a border tax have on the nation's economic conditions? 
- In 2018, Saudi Arabia imposed its first-ever value-added tax (VAT) of five percent on the consumption of most goods and services. What effects should a VAT have on Saudi Arabia's economic conditions?

- Bolivia relies heavily on exported commodities. What effects should falling world commodity prices (e.g., the prices of mineral fuels, ores, and precious metals) have on Bolivia's economy.

\section{Overview of the text}

Demystifying Global Macroeconomics is divided into six parts. Parts 1-5 build an integrated macroeconomic framework called the Three-Sector Model, which will be used to explain how economic, political, and social shocks can cause multiple and interrelated short-term economic changes. At each step of the way, you will be urged to ask yourself whether or not the economic concepts introduced and reasoning used meet your tests of common sense. Part 6 deals with long-term economic relationships. Let's look a bit deeper at these six parts to gain a better understanding of the topics they cover.

\section{Part 1 (Chapters 1 to 5)}

Part 1 focuses on how to measure a nation's economic health and monitor it for changes. Central to this discussion is understanding a nation's labor market conditions and the difference between real (i.e., inflation-adjusted) and nominal macroeconomic variables, such as gross domestic product (GDP), interest rates, and wages. One reason inflation is a central focus of any book on macroeconomics is because unexpected changes in inflation create economic beneficiaries and victims. Who are the victims and beneficiaries? Does inflation hurt a nation's overall standard of living or merely redistribute income and wealth among competing groups within the nation? Part 1 addresses these issues.

\section{Part 2 (Chapters 6 to 11)}

Part 2 focuses on financial markets. It begins by defining the most important monetary aggregates and then discusses the functions of money, as well as the important role of financial intermediaries and how they can create money. The ability to create money is a powerful one, so Part 2 explains central banks' monetary controls. With an understanding of the monetary aggregates and how 
they change, as well as how central banks regulate domestic liquidity levels, Part 2 then focuses on the real credit market, where the cost of real credit (also called the real interest rate) and quantity of real credit per period are determined by the forces of supply and demand. Part 2 ends with a discussion of cryptocurrencies, whether they are "money," their economic benefits, and the concerns that governments and central banks have about the effect they might have on nations' tax bases, monetary policies, and criminal activities.

\section{Part 3 (Chapters 12 to 14$)$}

Part 3 covers the real goods and services market, using aggregate supply and aggregate demand analysis to explain what causes a nation's real GDP and GDP Price Index to change. The effects of fiscal policies (i.e., government spending and taxation), automatic stabilizers, and business cycles (i.e., periodic economic expansions and contractions) are also explained in Part 3.

\section{Part 4 (Chapters 15 to 17 )}

Global macroeconomic topics are infused into this book from the beginning, but Part 4 dives more deeply into the international sector. We begin by discussing the foreign exchange market's structure, key market participants, and the effects that foreign exchange transactions have on nations' money supplies. Care is taken to explain how to read and understand currency quotations and to distinguish between bilateral and effective exchange rates, as well as nominal and real exchange rates. Part 4 goes on to address how the forces of supply and demand determine exchange rates and how changes in exchange rates affect countries' international competitiveness. Finally, Part 4 ends by focusing on how to read and interpret countries' balance of payments reports. It uses the International Monetary Fund's (IMF) approach to reporting balance of payments figures (rather than using any particular nation's approach) because IMF data can be used for cross-country comparisons. This chapter explains the most important balance of payments measures, what they reveal about a nation's economic conditions, and the ways in which managers can use them to make well-informed decisions concerning each world market in which they participate. 


\section{Part 5 (Chapters 18 to 21)}

Part 5 synthesizes the information from Parts 1 to 4 into the Three-Sector Model. At this point, you will understand: (1) how the real interest rate and the quantity of real credit per period are determined in the real credit market, (2) how the GDP Price Index and real GDP are determined in the real goods and services market, and (3) how the nominal exchange rate and the quantity of foreign exchange per period are determined in the foreign exchange market. The goal of Part 5 is to integrate these three markets and show how changes in one of them cause predictable changes in the other two.

The beauty of the Three-Sector Model is that it empowers you to conduct an economic analysis of any country, understand those of others, critically evaluate articles and editorials in the business media, such as The Wall Street Journal, Financial Times, and The Economist, to better formulate financial statement projections and contribute meaningfully to business strategy and planning discussions. Part 5 analyzes the short-term effects of shocks to countries with flexible and fixed exchange rates. Prominent in Part 5 is the role of international capital mobility ${ }^{1}$ and how its variations can affect economic outcomes. Part 5 ends with a case study of the Great Recession, which lasted from December 2007 to June 2009 and will be remembered by many as a low point in U.S. economic performance and financial regulation.

\section{Part 6 (Chapters 22 and 23)}

Part 6 opens our macroeconomic analyses to long-term business planning issues, which are particularly important to companies that are considering strategic maneuvers, such as mergers, acquisitions, and divestitures, as well as changes in sourcing, production, or marketing. This part begins by discussing scenario planning and the major causes of long-term development. Then, it explains comparative advantage, which demonstrates how open trade can be a win-win proposition. Part 6 goes on to explain why the economic reasoning behind good macro-level decisions at the national government level may be quite different from good company-level decisions. For instance, a nation's GDP is not like a company's gross sales revenues; most countries have their own currencies, but companies do not; a majority of countries consume internally most of what they produce and source

1 In general, international capital mobility is the responsiveness of global investment flows to relative international interest rate changes. 
from themselves the vast bulk of their needed inputs, but companies do not. Countries have full-employment targets and use monetary and fiscal policies to reach these goals, while nothing comparable exists at the company level. For these reasons, the best treasury officials, central bankers, and top-notch public policymakers may not be the most successful chief executive officers and chief financial officers. Part 6 then discusses monetarism, the quantity theory of money, causes of long-term inflation, and the long-run Phillips Curve, which addresses whether nations face a long-term trade-off between unemployment and inflation. The naturalrate hypothesis is used in this section to facilitate the discussion.

\section{What's new in the third edition?}

The third edition has already been tested on about 150 MBA students at Babson College, to whom I owe an enormous debt of gratitude for their thoughtful feedback and suggestions. Babson College's student population is highly international, which makes teaching this material a pleasure because it is like presenting global macroeconomics to a United Nations' audience. Knowing that English, for many of my students, is their second (or third, fourth, or more) language, I have reduced the length of this book and tried to keep it free of economic jargon. What jargon remains slipped past my best efforts and is purely unintentional.

In keeping with the second edition, I have separated each chapter into "The Basics" and "The Rest of the Story." "The Basics" section contains material that is essential to build a solid foundation in global macroeconomics. "The Rest of the Story" material provides students, professors, and other interested readers with flexibility to pick and choose topics of interest that support their time constraints and interests.

The chapter sequence and some of the titles, in the third edition, are slightly different from the second edition. Table P.1 highlights the similarities and differences. Two noticeable changes, which will be discussed below are: (1) the material on business cycles has been moved from Chapter 4, "Inflation, Real GDP, and Business Cycles" (second edition) to Chapter 14, "Business Cycles" (third edition), and (2) the material in Chapter 10, "The Economics of Virtual Currencies" (second edition) has been almost completely rewritten and placed into Chapter 11, "The Economics of Cryptocurrencies" (third edition).

Chapter 2, "Taking an Economic Pulse Beat" has been reorganized in the third edition by focusing "The Basics" on gross domestic product (GDP) and leaving nuances related to differences between GDP and gross national product (GNP) for "The Rest of the Story" section of the chapter. 
Table P.1: Table of Contents Comparison for DGM's Second and Third Editions.

\begin{tabular}{|c|c|c|c|}
\hline Chapter & Third Edition Chapter Title & Chapter & Second Edition Chapter Title \\
\hline FM & Preface & $\mathrm{FM}$ & Preface \\
\hline 1 & Introduction & 1 & $\begin{array}{l}\text { Introduction to International } \\
\text { Macroeconomics }\end{array}$ \\
\hline 2 & Taking an Economic Pulse & 2 & $\begin{array}{l}\text { Taking an Economic Pulse: Measuring } \\
\text { National Output and Income }\end{array}$ \\
\hline 3 & Labor Market Conditions & 3 & $\begin{array}{l}\text { Understanding and Monitoring Labor } \\
\text { Market Conditions }\end{array}$ \\
\hline 4 & Inflation and Real GDP & 4 & $\begin{array}{l}\text { Inflation, Real GDP, and Business } \\
\text { Cycles }\end{array}$ \\
\hline 5 & $\begin{array}{l}\text { Inflation: Who Wins, and Who } \\
\text { Loses? }\end{array}$ & 5 & Inflation: Who Wins, and Who Loses? \\
\hline 6 & Monetary Aggregates & 6 & $\begin{array}{l}\text { Monetary Aggregates: Measuring } \\
\text { Money }\end{array}$ \\
\hline 7 & Financial Intermediation & 7 & $\begin{array}{l}\text { Financial Intermediation, Markets, and } \\
\text { Intermediaries }\end{array}$ \\
\hline 8 & Money Creation & 8 & $\begin{array}{l}\text { The Power of Financial Institutions to } \\
\text { Create Money }\end{array}$ \\
\hline 9 & Central Banks & 9 & $\begin{array}{l}\text { Who Controls the Money Supply and } \\
\text { How? }\end{array}$ \\
\hline 10 & Real Credit Markets & 10 & The Economics of Virtual Currencies \\
\hline 11 & $\begin{array}{l}\text { The Economics of } \\
\text { Cryptocurrencies }\end{array}$ & 11 & Interest Rates and Why They Change \\
\hline 12 & Real Goods and Services Markets & 12 & Price and Output Fluctuations \\
\hline 13 & Fiscal Policy & 13 & $\begin{array}{l}\text { Fiscal Policy and Automatic Stabilizers: } \\
\text { What Managers Need to Know }\end{array}$ \\
\hline 14 & Business Cycles & 14 & Basics of Foreign Exchange Markets \\
\hline 15 & Foreign Exchange Basics & 15 & Exchange Rates: Why Do They Change? \\
\hline 16 & Foreign Exchange Markets & 16 & Balance of Payments Fundamentals \\
\hline 17 & Balance of Payments & 17 & Putting It All Together \\
\hline 18 & Putting It All Together & 18 & $\begin{array}{l}\text { Economic Shocks to Nations with } \\
\text { Flexible Exchange Rates }\end{array}$ \\
\hline
\end{tabular}


Table P.1 (continued)

\begin{tabular}{llll}
\hline Chapter & Third Edition Chapter Title & Chapter & Second Edition Chapter Title \\
\hline 19 & $\begin{array}{l}\text { Shocks to Nations with Flexible } \\
\text { Exchange Rates }\end{array}$ & 19 & $\begin{array}{l}\text { Economic Shocks to Nations with Fixed } \\
\text { Exchange Rates }\end{array}$ \\
\hline 20 & $\begin{array}{l}\text { Economic Shocks to Nations with } \\
\text { Fixed Exchange Rates }\end{array}$ & 20 & $\begin{array}{l}\text { Causes, Cures, and Consequences of } \\
\text { the Great Recession }\end{array}$ \\
\hline 22 & $\begin{array}{l}\text { Causes, Cures, and } \\
\text { Consequences of the Great } \\
\text { Recession }\end{array}$ & 21 & $\begin{array}{l}\text { Causes of Long-Term Growth and } \\
\text { Development }\end{array}$ \\
\hline 23 & $\begin{array}{l}\text { Long-Term Growth and } \\
\text { Development }\end{array}$ & 22 & $\begin{array}{l}\text { Long-Term Exchange Rate Movements } \\
\text { and Comparative Advantage }\end{array}$ \\
\hline RM & Inderm Inflation, Exchange & & \\
\hline EM & Abbreviations & EM & Index \\
\hline EM & $\begin{array}{l}\text { Important Macroeconomic } \\
\text { Relationships }\end{array}$ & EM & Abbreviations \\
\hline
\end{tabular}

The section in Chapter 3, "Labor Market Conditions" (third edition) entitled "Outsourcing, Offshoring, and Reshoring," starts by distinguishing among outsourcing, offshoring, and reshoring and then goes on to explain the likely longterm macroeconomic effects of offshoring. In the third edition, I try to do a better job explaining the significant short-term transitional costs associated with offshoring and, therefore, the ethical choices nations may face. This chapter reminds us that economics provides answers that should be nuanced and put into a broader perspective.

Chapter 4, "Inflation and Real GDP" (third edition) differs from the second edition by eliminating the discussion of business cycles. Instead, this material has been moved to Chapter 14, "Business Cycles" (third edition). As a result, the business cycle discussion is now much closer to Chapter 12, "Real Goods and Services Market" (third edition), where the causes of real GDP movements are discussed. Also moved from Chapter 4, "Inflation, Real GDP, and Business Cycles" (second edition) is the discussion of hyperinflation and deflation, which can now be found in Chapter 12, "Real Goods and Services Markets."

Chapters 6 to 10 (third edition) focus on U.S. and global financial markets. Chapter 6, "Monetary Aggregates" and Chapter 8, "Money Creation" (third edition) are similar to their counterparts in the second edition. Chapter 7 , 
"Financial Intermediation," has been supplemented by a section entitled Financial Disintermediation, Distributed Ledgers, Blockchain, and Smart Contracts. This material is sure to pique the interests of those curious about cryptocurrencies and their effects on nations' financial systems.

In Chapter 9, "Central Banks" (third edition), I have added a short discussion of microprudential and macroprudential regulations. In "The Rest of the Story" portion of this chapter, I have also included a brief discussion of various monetary policy targets, such as inflation rates, interest rates, money supply growth rates, GDP growth rates, and exchange rates. Removed from the third edition are the second edition's appendices, entitled "Who Regulates U.S. Banks," "Structure of the Federal Reserve System," "Who Controls the Fed?" “A Brief History of the Federal Reserve System," and “U.S. Dollar Facts and Figures."

In the third edition, substantial changes (mainly in terminology) have been made to the discussion of how interest rates are determined. Chapter 10, "Real Credit Markets" (third edition) replaces Chapter 11, "Interest Rates and Why They Change" (second edition). It focuses on the real credit market and cost of real credit (also called the real interest rate). The second edition focused on the real loanable funds market and real risk-free interest rate. The third edition brings the material in this chapter and its terminology into closer alignment with what we all read in newspapers and the financial news. I also added to Chapter 10 a short discussion of the liquidity trap, which has become a topic of discussion since the Great Recession (2007-2009). Removed from Chapter 10 (third edition) is the second edition's coverage of "Perfectly Mobile and Perfectly Immobile International Capital Markets.”

Chapter 11, "The Economics of Cryptocurrencies" (third edition) has been almost completely rewritten because so much has changed since publication of the second edition (i.e., Chapter 10, "The Economics of Virtual Currencies"). For instructors who can allocate a bit of extra time, this chapter promises to raise interesting questions for everyone in class. If the cryptocurrency markets grow to significant size, do they have the power to thwart central banks' abilities to control their nations' (or currency areas') money supplies and inflation rates? Do they undermine governments' tax bases and enable illegal financial activities, such as tax evasion and money laundering?

In the third edition, Chapters 12 to 14 focus on the real goods and services market. Chapter 12, "Real Goods and Services Markets" (third edition) replaces Chapter 12, "Price and Output Fluctuations" (second edition). Similarly, Chapter 13, "Fiscal Policy" (third edition) replaces Chapter 13, "Fiscal Policy and Automatic Stabilizers: What Managers Need to Know" (second edition). The content of Chapters 12 and 13 has been updated but, otherwise, it is very 
similar to the second edition. While the content of Chapter 13 (third edition) is similar to the second edition, the order in which the material is presented has changed. First, I moved the section entitled "Active versus Passive Deficits and Surpluses" from "The Basics" to "The Rest of the Story" and changed the terminology a bit. Instead of discussing "active" and "passive" deficits, I use the terms "structural" and "cyclical" deficits, which we see more often in the new media and academic literature.

In the third edition, Chapter 14, "Business Cycles" is now a new and separate chapter, but most of the material covered in this chapter was formerly in Chapter 4, "Inflation, Real GDP, and Business Cycles" (second edition).

In the third edition, Chapters 15 to 17 focus on foreign exchange markets and the balance of payments. Chapter 15, "Foreign Exchange Basics" (third edition) replaces Chapter 14, "Basics of Foreign Exchange Markets" (second edition). Removed from Chapter 15 (third edition) is the extended discussion of forward exchange markets, which was included in the second edition.

Chapter 16, "Foreign Exchange Markets" (third edition) is similar to its second edition counterpart, Chapter 15, entitled "Exchange Rates: Why Do They Change?"), but the appendix entitled "Can the Supply of Foreign Exchange Slope Downward?" has been removed.

Chapter 17, "Balance of Payments" (third edition) has been substantially revised-and for good reason. I have tried to make this book as current, readable, and useable as possible. To this end, I have chosen to focus on the IMF's presentation of nations' balance of payments statistics. In 2013, the IMF tried to make its balance of payments statistics more transparent and user-friendly by using rules and guidelines laid out in its report entitled Balance of Payments and International Investment Position Manual: Sixth Edition (BPM6). ${ }^{2}$ This new approach to measuring international transactions replaced the old version (BPM5), ${ }^{3}$ which was released in 1993.

Chapters 18 to 20 (third edition), put together everything you have learned from the beginning of the book. The terminology in these chapters, especially with respect to the real credit market and balance of payments, has been updated. In the third edition of DGM, important distinctions are made between shocks that have direct and indirect impacts on the economy and also between primary and secondary economic effects.

2 IMF, Balance of Payments and International Investment Position Manual: Sixth Edition (BPM6), 2013, https://www.imf.org/external/pubs/ft/bop/2007/bopman6.htm.

3 IMF, Balance of Payments Manual, 1993, https://www.imf.org/external/np/sta/bop/ BOPman.pdf. 
Chapter 19, "Shocks to Nations with Flexible Exchange Rates" and Chapter 20, "Shocks to Nations with Fixed Exchange Rates" (third edition) are similar to the second edition. To shorten the contents, I have removed from Chapter 20 the section entitled "Rise and Fall of the Asian Tigers: 1985-1997." The new end-of-chapter review and discussion questions should help compensate for this loss of material.

Chapter 21, "Causes, Cures, and Consequences of the Great Recession" (third edition) has been updated and carries the same name as Chapter 20 in the second edition. The new version discusses what has happened since the Great Recession ended.

Chapter 22, "Long-Term Growth and Development" (third edition) and Chapter 23, "Long-Term Inflation, Exchange Rates, and Unemployment” (third edition) are similar to Chapter 21, "Causes of Long-Term Growth and Inflation" (second edition) and Chapter 22, "Long-Term Exchange Rate Movements and Comparative Advantage" (second edition), but the content has been reorganized to match the new chapter titles. Removed from Chapter 21 (second edition) and placed into Chapter 23 (third edition) are discussions of the equation of exchange, monetarism, quantity theory of money, natural rate of unemployment, and Phillips Curve. Removed from Chapter 22 (second edition) and placed into Chapter 22 (third edition) are discussions of comparative advantage and why a country is not a company. 
